\title{
Psycholinguistic aspects of the process of perception of sound and color: THE PRoblem of NarRative discourse
}

Ivashkevych E. E. Psycholinguistic aspects of the process of perception of sound and color: the problem of narrative discourse / E. E. Ivashkevych // Problems of Modern Psychology : Collection of research papers of Kamianets-Podilskyi National Ivan Ohiienko University, G. S. Kostiuk Institute of Psychology of the National Academy of Educational Sciences of Ukraine / scientific editing by S. D. Maksymenko, L. A. Onufriieva. - Issue 39. - Kamianets-Podilskyi : Aksioma, 2018. - P. 101-110.

E. E. Ivashkevych. Psycholinguistic aspects of the process of perception of sound and color: the problem of narrative discourse. The author of this article underlines that studying narrative discourse in the English literature and its psycholinguistic aspects is very useful to admit at once that such kind of discourse plays a great role in all kinds of genre of fiction. In a case we have a deal with graphic novels it's more suitable to show and to underline psycholinguistic peculiarities or aspects of narrative discourse, in such a way, when we tell about perception of sound and color.

It was underlined that the important part of comic book narration was also the point of view: who was watching and what was the object of this gaze; if a character was looking at something and in the next panel we were shown this object of this gaze, the reader was positioned as this character. This type of positioning is essential in comic book narration, as it has the possibility of affecting the meanings linked with the reading of the comic.

It was shown that the type of transformation of visual information known to us from films, for example, visual images described personally characterized meaningful experiences of the character in the conditions of external focalization, thereby demonstrating that the character had survived in the past. It was proved that when a person was reading a novel, it was easy to see how the usage of visual elements had to ensure the accuracy of the perception of transient moments in space and time. It was a practical advantage of so-called visual style, which was much more effective than words. This visualization in time and space was, in fact, an important quality of the novel "Watchmen», which helped us to understand its profound interpretation, which was one of the most important characteristics of a graphic novel.

Analyzing «Watchmen», the author of this article proposed such psycholinguistic aspects of narrative discourse, as: visual emphasis; focaliza-

(C) E. E. Ivashkevych 

tion of information; epigraphs' emphasis; meta-narrative presentation of the text; contrasting visual linkings; actualization of narrative potential.

Key words: narrative discourse, visual emphasis, focalization of information, perception of sound and color, meta-narrative presentation of the text, contrasting visual linkings, actualization of narrative potential.

Е. Е. Івашкевич. Психолінгвістичні аспекти процесу сприйняття звуку і кольору: до проблеми наративного дискурсу. У статті наголошено, що вивчення наративного дискурсу на прикладі англійської літератури, визначення психолінгвістичних аспектів такого дискурсу є вельми актуальною проблемою сучасності, адже такого роду дискурс відіграє неабияку роль у всіх жанрах художньої літератури. Наративний дискурс проаналізовано на прикладі графічних романів, на основі аналізу яких визначено психолінгвістичні особливості наративного дискурсу, в тому числі, коли йдеться про сприйняття звуку та кольору.

Зазначено, що важливим для окреслення особливостей наративного дискурсу є аналіз матеріалів, представлених у вигляді коміксів, адже людина, яка спостерігає, є лише об’єктом візуалізації, а не її суб'єктом. Наголошено на ролі візуальних образів, які допомагають читачеві зрозуміти текстову інформацію. Показано, що за допомогою повторення візуальні образи стають символами, які означають, що вони починають представляти дещо інше за допомогою певного правила або їхнього особистісного сприйняття.

Показано, що тип перетворення візуальної інформації, відомий нам із фільмів, а саме візуальні образи, описують особистісно значущі переживання персонажа за умов зовнішньої фокалізації, тим самим демонструючи, що персонаж пережив у минулому. Доведено, що, читаючи роман, легко помітити, як використання візуальних елементів для забезпечення точності сприйняття перехідних моментів у просторі й часі є практичною перевагою так званого візуального стилю, який набагато ефективніший за слова. Ця візуалізація у часі й просторі в дійсності є невід’ємною складовою роману «Нічні охоронці», яка призводить до його глибокої інтерпретації, що є однією з найважливіших характеристик графічного роману.

Аналізуючи твір «Нічні охоронці» Алана Мура та Дейва Гіббонса, автором статті запропоновано такі психолінгвістичні аспекти наративного дискурсу: візуальна акцентуація, актуалізація інформації, актуалізація епіграфа, метанаративна презентація тексту, контрастні візуальні словосполучення, актуалізація наративного потенціалу.

Ключові слова: наративний дискурс, візуальна акцентуація, актуалізація інформації, сприйняття звуку та кольору, метанаративна презентація тексту, контрастні візуальні словосполучення, актуалізація наративного потенціалу.

The topicality of the research. Studying narrative levels of graphic novels, it is naturally to be located in the field of narrative 
studies and it will attempt to mould a narrative method suitable for studying of graphic novels, for studying of the world of image. As any established method doesn't exist yet, this article we'll begin by combining various theoretical researches from the field of traditional narrative studies, such as Seymour Chatman and Gerard Genette, with various views on visual narration and researches of studying comics. A basic structural analysis of «Watchmen» (1986) by Alan Moore and Dave Gibbons is the initial goal, and later chapters will attempt at more detailed analysis of the various narrative aspects of a graphic novel. It is important to point out right at the beginning that in the context of this study, the general terms of traditional narrative study are not directly applicable, but must be reconsidered and possibly redefined when applied. Therefore, terms such as narrative studies poorly, as no single narrator can be extracted from the story appearing in a graphic novel, as the images are not «narrated» in a way traditional written novels are. It is more useful to borrow the term "narration" from the field of film studies. Still, in this thesis the terms from narrative studies will be applied from the point of view of comic book narration and its requirements.

The review of recent researches. As we know, comics are formed from images, words and the union of them, and it is impossible to find a single dominant narrative level typical to traditional narrative literature, which has traditionally been divided into retrospective first-person narrative, self-reflective narrative, objective third-person narrative, an omniscient narrative, focalized narrative or stream-of-consciousness-type of narrative. These are not alone sufficient in a study of visual narration, which is usually divided between narrator, narrative level and so called «point of view», but these terms are not used in the same way as they would be used in basic literary studies, for the narrator of the comic book does not have to describe the characters or the settings around him, because they are immediately available to the reader in a visual form. The setting of the comic is therefore important, the events-on-scene are what it is shown and how it is shown. The various narrative devices of the comic book can also enable to reader to identify to the characters in a new way by concretely positioning the reader inside the point of view of a certain character. We'll present some of the basic theoretical tools and concepts this article will rely on as well as some of the reasons for choosing these particular approaches. As the study of comics and the terms linked with it are not yet widely known, the basic concepts related to it will also be presented. 
The researcher Seymour Chatman divided the narrative text into two components, which will be referred to here as story (what happens?) and narrative (how it happens?). The story is further divided into events and existents, which are composed of subcategories such as actions, happenings, characters and setting [1, p. 19]. "Watchmen" also can be divided into story and narration, the story being the abstract plot of superheroes uncovering a plot to kill millions of people, and the narrative is the arrangement of the events of the plot in a given medium (here comics) that actualizes the story [1, p. 37]. The narrative structure in "Watchmen" plays with temporal levels and concepts, showing the reader events and actions from the past, present and sometimes even the future, many of them almost simultaneously by the way of juxtaposing panels from separate temporal levels. A past act can be shown to the reader in connection to the present action, thus giving both events new contexts and new meanings' by associating them with each other [1].

Gerard Genette will be another essential classical narratologist in this research, as the term narration itself comes from him, as well as the idea of a focalizer, both of which are essential to narratological study, and of great interest in the study of graphic novel narration, for focalization in comics has possibilities beyond traditional literature. In his Narrative Discourse [2, p. 114-116] G.Genette also refers to frequency, which he uses to describe the way certain elements are repeated in the story and how often the certain event is told. The event cannot be told exactly the same way each time, but it is always bound to different contexts and thus creates new meanings and is connected to new thematic ideas every time. According to G.Genette, a text can hold several abstract and thematically motivated events that are repeated in different parts of the narration. Considering the temporal structures in graphic novels, frequency is an important concept in this study since certain images appear repeatedly in "Watchmen", each time in slightly different contexts, thus creating new meanings. Some events are also repeated from different perspectives, variations in point of view, which is a narrative device labeled by G.Genette as repeating narrative [2, p. 114-116]. This type of repeating can also involve only stylistic variations, but the changes in the point of view is the aspect of repeating narrative that will be applied in this research.

So, the tasks of our research are:

1. To analyze the narration of «Watchmen» and to show emphasis of perception color and sounds. 
2. To study psychological characteristics of narrative level of graphic novels.

3. To propose psycholinguistic aspects of narrative discourse.

The main material of the research. Traditional narratology as it is does not provide sufficient tools for graphic novel analysis, as the medium is visual in a way written literature is not and the written narrative is usually privileged above the visual, as already mentioned in the previous section. However, rather than creating a whole new method for the narratological analysis of comic books, this thesis will apply these traditional views as far as they can be useful, and continue to build new concepts with the help of other theorists when this approach fails. A transition in theoretical approach from classical to post-classical narratology will take place during this research, as traditional approaches will gradually be supplemented with views from cognitive sciences and later developments from the field of narratological studies.

One of the most typical and widely-used means comics have is the usage of the word balloon. It is the icon of the comic book form, to which Scott McCloud refers as a «desperation device» [3, p. 26] due to its impossible mission: the attempt to visually communicate sound. Scott McCloud [3, p. 134-135] has illustrated the onomatopoetic possibilities of the word balloon; according to him, both the shape of the balloons and the lettering styles inside them "speak of an ongoing struggle to capture the very essence of sound" [3, p. 134]. Some of the characters in the comic book have a special lettering style and a specific kind of word balloon, in which the visual and verbal expression combine together in order to create onomatopoetic signs, in which the graphic layout complements the meaning of the words. As already briefly mentioned in section three of this thesis, the bolding of specific words acts as a way of bringing emphasis to these words, stressing their importance: McCloud has even gone so far as to suggest that the reader «should be able to get the thrust or sense of the dialogue out of the bold-face letters alone» [3, p. 152]. In «Watchmen», the speech balloons are standard, round and smooth, with the exceptions of Rorschach and his wavy lines and Dr. Manhattan, whose intense blueness reaches even his speech balloons. Dr. Manhattan's gradual withdrawal from the world of human beings is stressed also in his speech balloons, which have double lines whereas others have single lines - a unique way of hinting at his increasing detachment and separation. Rorschach, as mentioned, has a distinctly unique word balloon style: 
his speech balloons have wavy, almost slurry edges, which create a somewhat moist and muffled idea of speech as opposed to the usual straight and clear lines of normal speech balloons. His voice, described as horrible and «monotone» by Laurie [4, p. 23], lacks all the bold-face words, creating indeed the feeling of a monotonous speech without any stresses. It is noteworthy to mention that once he is captured and his mask has been taken off, his speech balloons alter to look like everyone else, that is the "normal» speech balloon, although still without any stresses. The effect of the mask he wears on his speech is clear, as the quality of his voice alters depending on whether the mask is on or not. However, a more careful inspection of Rorschach's speech balloons reveal that his speech balloons were "normal», round and smooth and with bolded words in his past even with his mask on, as a past scene located in 1966 demonstrates [I4, p. 10-11]. It is therefore to be assumed that his speech did not acquire the "Rorschach-quality" of wavy edges and zero stress until 1975, as he himself recounts his traumatic «birth» as Rorschach to Dr. Long in Chapter VI. His speech echoes, among all other things, also the shift in his mental state, the movement "over the edge» that took place, causing him to become what he is. This type of visual information concerning speech is unique to the medium of comics, and serves many purposes from recognition to onomatopoeia. An important aspect to notice concerning sound in "Watchmen" is the complete lack of sound effects. This lack of effects is noteworthy, for the general opinion among comics researchers is that sound effects are one of the essential qualities of comics. Graphic sound effects ( $\mathrm{Pow}$ !», «Ka-Boom!» etc.) have become almost a trademark of superhero comics, even though their use increases the feeling of detachment on the part of the reader. This detachment may arise from the "double effect» of both seeing the action itself as well as the seeing the «sound» it causes - just seeing the action can alone create the sound images in the readers mind. Just like spoken language is not seen in real life, neither are the sound effects of violent action. Thus, by avoiding the use of sound effects and leaving the sounds to the imagination of the reader, "Watchmen" manages to bring the reader closer to the action, more intertwined with the narration, become a part of it, an active participant in the creation of a narrative from sequential images.

The contradictory element here is, of course, the unavoidable existence of speech balloons, which convey the dialogue to the reader in written form, which could hardly be described as "realistic». 
However, comic book speech acts do not generally have the same visual effect as violent action, as the movement caused by speech is hardly visible - the aforementioned "double effect» is absent from the dialogues, thus eradicating the problem of both seeing the action and seeing the sound. The use of "motion lines» indicating movement is also very limited, which results in the fact that the imagery is one of photorealism, of completely «still» images that create sequential motion. Dave Gibbons has discarded all of these traditional elements of comic book action, which actually produces a stronger image of reality, for sounds are not «seen" in real life; "Watchmen" also rejects the use of thought balloons, probably for the same effect of realism.

As the second of this chapter's "extranormal operatives», the coloring of the graphic novel is a factor not to be overlooked. As Scott McCloud points out, black and white - comics have a tendency to transfer the ideas behind the art, meaning transcending form, whereas in color comics the colors themselves take on more significance [4; p. 192]. Unfortunately, this often implies that the more "serious» work is done in black and white, while the colored comics have the status of entertainment. "Watchmen», however, challenges this stereotypical assumption. Dave Gibbons has used very bright colors, the trademark of American superhero comics, which according to Scott McCloud originated from the competition to stand out from the normal black-and-white look of the newspapers: «...costumed heroes were clad in bright, primary colors and fought in a bright primary world!» [4, p. 103]. Because the colors of superheroes' costumes remained the same from panel to panel, the colors they wore came to symbolize the characters in the mind of the reader [4, p. 103]. Thus Dr. Manhattan's bright blue coloring begins to symbolize him in Watchmen, and dominates his narration, his captions and his world to the point that when the color appears, the narrative schema concerning him will automatically activate. The panels with the red shade create an immediate feeling of threat, as it has been associated with a brutal murder scene during the initial pages of the graphic novel. Coloring plays a crucial role in the «modern mythology» of the superhero, as symbols are a part of the «stuff of which Gods are made» [4, p. 103].

The colors can also express mood, become more subjective and thus affect narration. As mentioned, in Watchmen the dominant color in certain scenes is that of crimson, almost dark pinkish red the same far too bright color is also used for blood in the comic. This 
red tint shades the Comedian's death scene right in the beginning, and later when the images of the scene reoccur, they are continuously red, creating an atmosphere of threat and anxiety. There is a visible change in coloring between the main story of «Watchmen» and the Black Freighter - comic read inside it, and the doubly-fictional pirate comic has a distinguished color pattern of cruder and cheaper appearing color division than «Watchmen», implying its "superhero comic-nature» in the fictional universe of "Watchmen». The pirate comic with its bright green and yellow is the cheap entertainment that superhero comics have been labelled as in our world, and they are made with low costs for the buying masses. The appendix consists of a praising article on the "creators" of the Black Freighter - pirate comic, ironically mocking the similar praises done on Moore and Gibbons. As letterer, Gibbons even goes out of his way to draw different styles of speech balloons and captions based on the pirate comic character and the time period.

The coloring serves also as a timing device, as Gibbons uses the blinking streetlight outside Moloch's apartment [4, p. 22-23] to serve as a visual reminder of the parallel storylines of Watchmen, even though this time the narrative is single, and no parallel shift appears. This also works as a way for the reader to follow the time frame: every other panel is a gloomy yellow, while other is dark, thus pacing the action in a more uncommon way. The temporality of the narration can also be created through coloring in the sense that a past storyline can be juxtaposed with a present one, and the distinction between past and present is created through shading the past storyline with a single color, thus immediately separating all the images belonging to that particular time level as their own distinct whole. One such instance is the murder scene of the Comedian right at the start of the graphic novel. The coloring serves various functions in the narrative structures of Watchmen, it symbolizes, it gives the narrative rhythm, it creates the mood.

Therefore, a narratological method suitable for the study of comics must take into account the both forms that define comics: both the content and the artwork contained in the panels. In addition to this, textual elements contained within the comic book need to be taken into account, as a part of a carefully constructed interplay between words and images.

As in many of the graphic novels of the late 1980s, the city of New York offers an urban setting, a place with little or no hope, 
a city where traditional authority figures are incapable of dealing with civic problems or criminal activity. The "watchmen», though never explicitly named so, are the so-called superheroes, already outlawed in 1977 by the fictionally transformed "Keene Act», and are now either retired or choosing the life of outlaw vigilantes, still hiding their true identities behind masks. As one of their kin is brutally murdered, they slowly begin to discover a much larger plot, designed by Adrian Veidt (previously superhero Ozymandias) to unite mankind by very questionable methods. Apart from the powerful visual narration, Watchmen relies on many textual devices unusual to graphic novels to narrate the story, ranging from personal diaries to scientific articles and newspaper clippings, which all weave new layers and meanings to the already complex narration. Also, each of the twelve chapters ends with a short epigraph, a quotation ranging from rock lyrics to nineteenth-century poetry. Each epigraph underlines the theme of the chapter and can therefore be seen as affecting the cognitive schemas and interpretations the reader develops of given chapters.

Conclusion. So, analyzing "Watchmen» and describing psychological characteristics of narrative level of graphic novels we can propose such psycholinguistic aspects of narrative discourse:

- visual emphasis;

- focalization of information;

- epigraphs' emphasis;

- meta-narrative presentation of the text;

- contrasting visual linkings;

- actualization of narrative potential.

Also "Watchmen" as the socio-cultural phenomenon has been studied in the courses of history, economy, politics and sociology, while there have been no psycho-linguistic study on the novel. In other our articles we'll decide to focus mostly on the culturelogical aspects of the novel, and the results of these researches will be discussed and completely described.

\section{References}

1. Chatman S. Story and Discourse. Narrative Structure in Fiction and Film / Seymour Chatman. - New York : Cornell University Press, 1978. -98 p.

2. Genette G. Narrative Discourse. An Essay in Method. Trans / Gerard Genette. - New York : Cornell University Press, 1980. $136 \mathrm{p}$. 
3. McCloud S. Understanding Comics. The Invisible Art / Scott McCloud. - New York : HarperCollins, 1993. - 220 p.

4. Moore A. \& Gibbons D. Watchmen / Alan Moore \& Dave Gibbons. - London : Titan Books (DC Comics), 1987. - 108 p.

Received October 24, 2017

Revised November 20, 2017

Accepted December 18, 2017

\section{МисленНєві Стратегї̈ ЯК МеХАНізМ РОЗВ' ЯЗУВАННЯ НЕСТАНААРТНИХ КАінічнИХ ЗАААЧ}

Kyshakevych I. T. Thinking strategies as a mechanism for solving non-standard clinical problems / I. T. Kyshakevych // Problems of Modern Psychology : Collection of research papers of Kamianets-Podilskyi National Ivan Ohiienko University, G. S. Kostiuk Institute of Psychology of the National Academy of Educational Sciences of Ukraine / scientific editing by S. D. Maksymenko, L. A. Onufriieva. - Issue 39. - KamianetsPodilskyi : Aksioma, 2018. - P. 110-122.

I. T. Kyshakevych. Thinking strategies as a mechanism for solving non-standard clinical problems. Findings of studying psychological essence of doctors' thinking patterns used while solving non-standard clinical problems have been highlighted.

According to the findings of clinical thinking analysis, its creative nature has been proved as well as the approach to its study via the analysis of thinking practices in solving non-standard clinical problems has been defined. The author has singled out three components of creative clinical thinking process, i.e. the process of understanding, the process of prognosis and the process of approbation, and has analyzed searching actions applied to such components.

The approach to doctor's creative thinking study through the analysis of prevailing thinking practices in solving non-standard clinical problems has been defined. It has been established that actions according to analogy, against analogy and combinatorial actions occur in each component of creative clinical thinking process; besides, their contents in the process of 